\title{
UPAYA MENINGKATKAN HASIL BELAJAR PASSING BAWAH PERMAINAN BOLA VOLI MELALUI GAYA MENGAJAR LATIHAN PADA SISWA KELAS X SMA SWASTA DARUL ILMI MURNI KABUPATEN DELI SERDANG TAHUN AJARAN 2017/2018
}

\author{
${ }^{1}$ Indrakasih \\ ${ }^{2}$ Salman \\ Correspondence: Universitas Negeri Medan, Medan, Indonesia \\ E-mail: Indra_ksh@yahoo.co.id
}

\begin{abstract}
Abstrak
Penelitian ini bertujuan untuk menemukan Informasi pemanfaatan penerapan gaya mengajar latihan dalam menunjang pembelajaran pendidikan jasmani terhadap hasil belajar passing bawah bola voli kelas X SMA Swasta Darul Ilmi Murni tahun ajaran 2017/2018. Sampel dalam penelitian ini adalah kelas siswa $X$ dengan jumlah siswa 22 yang akan diberikan tindakan berupa pengajaran melalui penerapan gaya latihan terhadap hasil belajar passing bawah bola voli. Untuk memperoleh data dalam penelitan ini maka dilakukan tes hasil belajar I yang berbentuk portofolio passing bawah bola voli. Setelah data terkumpul dan dilakukan analisis maka diperoleh hasil analisisnya: (1) Dari hasil belajar I diperoleh 11 siswa atau $50 \%$ siswa yang telah mencapai ketuntasan belajar, sedangkan 11 siswa 50\% siswa belum mencapai ketuntasan belajar. Dengan nilai rata-rata hasil belajar siswa 75. (2) Dari tes hasil belajar II dapat dilihat kemampuan siswa dalam melakukan tes hasil belajar secara klasikal sudah meningkat. Terdapat 19 siswa atau $86.36 \%$ yang telah mencapai ketuntasan belajar, sedangkan 3 siswa $13.63 \%$ belum mencapai ketuntasan belajar. Dengan nilai rata-rata hasil belajar sisawa adalah 83.45. Berdasarkan hal itu maka dapat ditarik kesimpulan bahwa pembelajaran melalui penerapan gaya mengajar latihan dapat meningkatkan hasil belajar passing bawah bola voli pada siswa kelas $X$ SMA Swasta Darul Ilmi Murni Medan Johor Tahun Ajaran 2017/2018.
\end{abstract}

\section{Kata Kunci: Gaya Mengajar, Latihan Passing Bawah}

\section{Pendahuluan}

Pendidikan dan pembinaan jasmani adalah sebagian dari persiapan pembentukan manusia seutuhnya. Persiapan ini dilakukan melalui usaha pembinaan keterampilan fisik dan dilaksanakan dalam bentuk interaksi belajar mengajar dan berlatih. Dalam interaksi intruksional, seorang diajar suatu bentuk keterampilan gerak tertentu. Gerak itu dilakukan hingga berulang-ulang hingga menjadi gerak yang mahir, efektif dan efisien. Proses demikian akan memerlukan petunjuk dan bimbingan dari seorang guru atau pelatih yang berpengetahuan dan berpengalaman.

Sekolah adalah sebagai lembaga pendidikan formal, bertugas sebagai penyelenggaraan pembinaan mental-spritual, intelektual dan khususnya pembinaan kualitas fisik melalui program pendidikan jasmani. Dalam hal ini, cara pemberian latihan maupun pelaksanaan proses belajar mengajar perlu 
diperhatikan sehinga anak didik, guru dan pelatih tidak membuang waktu dan tenaga sehingga hasil terbaik yang diharapkan tetap tercapai.

Kegagalan dari usaha pencapaian tujuan yang telah diprogramkan disebabkan kurangnya pengetahuan dalam hal pemberian latihan atau ketidak mampuan untuk memilih metode atau gaya mengajar yang akan dipergunakan sehingga anak didik tidak dapat mencapai hasil maksimal seperti yang diharapkan. Banyak faktor yang mempengaruhi untuk mencapai hasil yang baik. Dari suatu proses instruksional pendidikan jasmani dimana salah satunya adalah sistematika dari cara pemberian pelajaran dan pembelajaran.

Pada hakikatnya pendidikan adalah suatu proses interaksi yang bersifat manusiawi, upaya untuk menyiapkan peserta didik, upaya untuk meningkatkan kualitas hidup, kegiatan yang dilakukan seumur hidup, serta upaya dengan senantiasa menerapkan prinsip-prinsip iptek. Penerapan yang dimaksud adalah hubungan timbal balik (komunikasi dua arah).

Charles Bucher, dalam bukunya Foundation of Phsical Education (1972) pendidikan jasmani adalah bagian yang terpadu dari proses pendidikan yang menyeluruh; bidang sasaran yang diusahakan adalah perkembangan jasmaniah, mental, emosional, dan sosial bagi warga negara yang sehat, melalui medium kegiatan jasmaniah.

Menurut Abdul Gafur (dalam Arman Abdullah 1994):" Pendidikan jasmani adalah suatu proses pendidikan seseorang sebagai perorangan maupun sebagai anggota masyarakat yang dilakukan secara sadar dan sistematik melalui kegiatan jasmani yang intensif dalam rangka memperoleh peningkatan kemampuan dan keterampilan jasmani, pertumbuhan kecerdasan dan pembentukan watak “. Sedangkan menurut Rusli Lutan (2000) menjelaskan penjas adalah wahana untuk mendidik anak muda agar kelak mereka mampu membuat keputusan terbaik tentang aktivitas jasmani yang dilakukan dan menjalani pola hidup sepanjang hayat.

Hasil belajar merupakan penguasaan terhadap sesuatu yang di peroleh dalam belajar, sesuatu yang di peroleh berbeda-beda yakni ada yang memperoleh hasil yang tinggi dan rendah. Melalui kegiatan belajar mengajar secara perlahanlahan akan terjadi perubahan pada individu yang belajar baik dari pengetahuan, sikap, dan keterampilan.

Menurut Husdarta (2000), "belajar adalah perubahan tingkah laku sebagai akibat adanya interaksi antar individu dengan lingkungannya". Selain itu, menurut Nana Sudjana (2009), "hasil belajar pada hakikatnya adalah perubahan tingkah laku yang mencakup bidang kognitif, afektif, dan psikomotorik". Sedangkan Menurut Djamarah (2006), hasil belajar adalah terjadinya perubahan tingkah laku pada diri siswa yang dapat diamati dan diukur dalam bentuk perubahan pengetahuan, sikap, dan keterampilan.

Menurut slameto (1988) dalam buku Mardianto belajar adalah suatu proses usaha yang dilakukan individu untuk memproleh suatu perubahan tingkah laku yang baru secara keseluruhan, sebagai hasil pengalaman individu itu sendiri dalam interaksi dan lingkungannya. Jadi, dapat disimpulkan bahwa perubahan kemampuan dalam diri siswa berupa pengetahuan, sikap dan keterampilan yang 
diperoleh setelah mengalami interaksi proses pembelajaran dan setelah dilakukan suatu tes dan diperoleh nilai. Selanjutnya menurut Bloom (2009) hasil belajar secara garis besar dapat dikelasifikasikan menjadi tiga ranah yaitu:

1) Ranah kognitif berkenaan dengan hasil belajar intelektual meliputi pengetahuan,pemahaman, aplikasi, analisis, sintesis, evaluasi.

2) Ranah efektif berkenaan dengan sikap meliputi penerimaan, jawaban, penilaian,organisasi dan internalisasi.

3) Ranah psikomotorik berkenaan dengan hasil belajar keterampilan dan kemampuan bertindak meliputi gerak reflex, keterampilan dasar, ketepatan, gerakan keterampilan komplek, dan gerakan ekspresif dan interaktif.

Setiap apa yang dilakukan pasti akan mendapatkan hasil yang diinginkan. Begitu juga dengan belajar, perubahan dalam hasil belajar dapat berupa perkembangan pengetahuan, sikap, keterampilan yang diharapkan mampu mencegahkan masala-masalah atau tuntutan hidupnya. Karena itu seseorang dikatakan belajar jika dalam diri orang tersebut terjadi suatu proses yang perubahan tingkah laku merupakan proses belajar sedangkan tingkah laku merupakan hasil belajar.

Permainan bola voli diciptakan oleh William G. Morgan pada tahun 1895. Dia adalah seorang pembina pendidikan jasmani pada organisasi "Young Man Christian Association" (YMCA) di kota Massachusett, Amerika Serikat. Mulamula permainan bola voli diberi nama "mintonette" dimana permainannya hampir sama dengan permainan badminton. Jumlah pemain tidak terbatas, sesuai dengan tujuan semula yaitu untuk mengembangkan kesegaran jasmani para buruh disamping bersenam umum. Nama permainan ini di ubah menjadi volley ball kurang lebih menvoli bola secara bergantian. Pada tahun 1902 YMCA berhasil mengadakan kejuaraan nasional bola voli di negara Amerika Serikat. Kemudian pada tahun 1948 IVBF (International Volley Ball Federation) didirikan, yang beranggotakan 15 negara dan berpusat di Paris.

Menurut Oky susanto teknik dasar passing ini diberikan untuk membangun sebuah serangan dalam permainan bola voli, dan sangat diperlukan saat tim menghadapi lawan yang kuat oleh karenanya diperlukan passing untuk membangun tim yang kuat. Sedangkan Menurut G. Durrwachter yang paling baik untuk memperkenalkan teknik passing bawah ialah apabila pemain sudah secara otomatis menuju posisi yang tepat serta sudah terbiasa cepat-cepat bergerak kearah bola.

Dari penjelasan diatas dapatlah dikemukakan bahwa keterampilan memainkan bola melalui passing mutlak perlu dikuasai. Selanjutnya passing dalam permainan bola voli ada 2(dua) jenis yaitu passing atas dan passing bawah. Pada dasarnya kedua jenis passing ini bertujuan untuk mengoper bola pada teman satu regu dan selanjutnya diharapkan dapat melakukan penyerangan kembali kepada regu lawan.

Passing bawah digunakan untuk menerima sevis, menerima spike, memukul bola setinggi pinggang kebawah, dan memukul bola yang memantul dari net. Teknik kebanyakan hanya digunakan menerima bola, maka teknik 
biasanya isebut sebagai operan (Barbara L. Viera, 2004). Sedangkan Menurut Beutelstahl, Dieter (1984) passing bawah yang merupakan satu satunya cara untuk menerima servis yang digunakan lawan sedini mungkin. Sipenerima servis harus berusaha mengetahui jenis servis yang digunakan lawan sedini mungkin. Menurut Barbara L. viera, Bonnie Jill Fergusson (2004) "teknik gerakan passing bawah di bagi menjadi tiga bagian diantaranya: (1) Sikap Persiapan, (2) sikap perkenaan dan (3) sikap Akhir".

a. Sikap Persiapan: Ambil posisi sikap siap normal lutut di tekuk sedikit sehingga tubuh bagian atas membungkuk sedikit kedepan. Pada saat tangan akan dikenakan bola, segera tangan dan lengan diturunkan dalam keadaan terjulur kebawah dengan siku lurus. Siku tidak ditekuk pada waktu akan menyentuh bola pada bagian sebelah atas dari pergelangan tangan, terlebih dahulu ambillah posisi yang baik sehingga badan berada pada posisi menghadap bola.

b. Sikap Perkenaan/pelaksanaan: Pada saat akan mengenakan bola pada bagian sebelah atas dari pada pergelangan tangan, ambillah terlebih dahulu posisi sedemikian rupa sehingga badan berada pada poisi menghadap bola. Bagian bola berada pada jarak yang tepat maka segeralah ayunkan lengan yang telah lurus dari arah bawah ke atas depan. Tangan pada saat itu telah berpegangan satu sama lain. Perkenaan bola harus diusahakan tepat pada bagian proksimal dari pada pergelangan tangan dan bidang yang selebar mungkin agar bola dapat melambung secara stabil, maksudnya agar selama dilintasannya bola tidak banya membuat putaran.

c. Gerakan Lanjutan/Sikap Akhir: Setelah bola berhasil di passing bawah maka segerelah diikuti pengambilan sikap normal kembali dengan tujuan agar dapat bergerak lebih cepat untuk menyesuaikan diri dengan keadaan. Beuthelstahl, Dieter (1984) menambahkan " setelah gerakan perkenaan bola diteruskan dengan follow through, kemudian mengambil posisi berikutnya mempersiapkan diri menerima pukulan atau serangan dari musuh".

Menurut Moston (1981) mengatakan "Gaya mengajar latihan adalah memberikan waktu kepada siswa untuk melaksanakan tugas secara individual dan waktu yang diberikan guru untuk memberikan umpan balik kepada seluruh siswa secara individual.

Gaya mengajar latihan ini dapat diartikan sebagai suatu cara mengajar dimana siswa memiliki ketangkasan atau keterampilan yang lebih tinggi dari apa yang telah dipelajari, Roestiyah N.K (2008). Latihan yang praktis, mudah dilakukan, serta teratur melaksanakannya dapat membina anak dalam meningkatkan penguasaan keterampilan itu, bahkan mungkin siswa dapat memiliki ketangkasan itu dengan sempurna. Hal ini menunjang siswa berprestasi di bidang olahraga yang ditekuninya.

Gaya latihan ini memberikan siswa untuk berlatih secara individu dan mandiri, serta menyediakan guru waktu untuk memberikan umpan balik (feedback) kepada siswa secara individu dan pribadi. Peserta didik mengerjakan 
tugas yang diberikan oleh guru. Dalam model tugas, guru mendelegasikan sebagian kewenangannya pada peserta didik. Guru memberikan tugas belajar gerak, idealnya secara tertulis berupa kartu tugas, peserta didik diberi kesempatan dan kewenangan untuk menentukan sendiri kecepatan dan kemajuan belajarnya.

Dalam anatomi digaya latihan, guru membuat semua keputusan pada pra pertemuan dan pasca pertemuan. Pada pertemuan, guru memberikan keputusan kepada siswa. Siswa menampilkan tugas yang telah diberikan oleh guru. Perpindahan keputusan ini merupakan awal mula proses individu dalam menampilkan perilaku guru dan siswa.

Berikut ini merupakan bentuk bentuk latihan yang akan dilakukan oleh siswa untuk meningkatkan hasil belajar teknik passing bawah/operan lengan depan;

1. Melakukan operan passing bawah melewati kepala rekan, latihan ini membantu untuk melatih siswa dalam menerima bola pada posisi rendah dan mengarahkannya kedepan. Karena bolanya tak bergerak, maka anda memusatkan perhatian pada cara menerima bola dan posisitubuh tanpa harus melakukan gerakan kearah bola. Kesulitannya adalah untuk mengarahkan bola melewati kepala rekan anda, yang akan terjadi bila anda tidak menerima bola jauh dari tubuh anda. Cara latihannya adalah Mintalah rekan anda untuk memegang bola setinggi pinggang anda, gunakan operan lengan depan/passing, pukul bola dari rekan anda sehingga bola terarah kebelakang rekan anda. Rekan anda kemudian menangkap dan latihan terus dilanjutkan. Tujuan kesuksesan 25 kali operan lengan depan/passing bawah yang baik dari 30 usaha; (a) pemeriksaan kesuksesan, (b) bola dipegang pada posisi rendah, (c) berat badan diarahkan kedepan, (d) lengan sejajar dengan paha

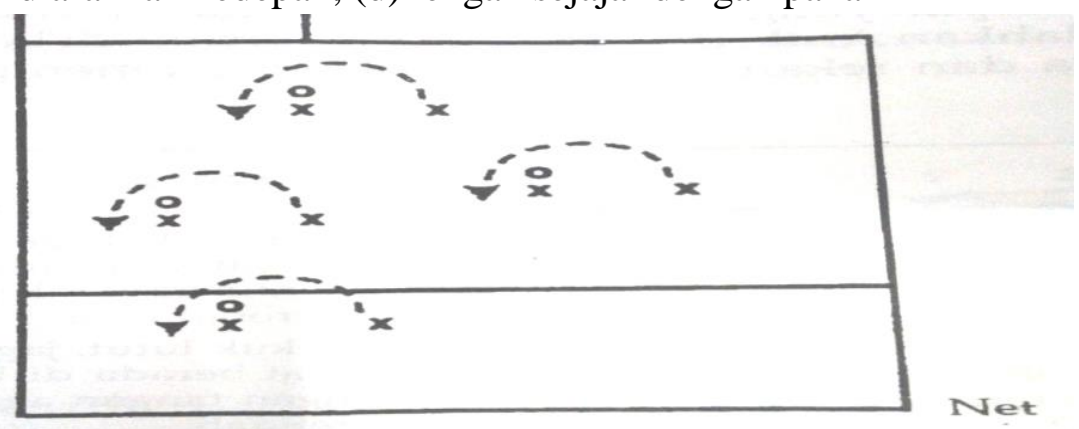

Gambar 1. Latihan Bola Tidak Bergerak, Barbara L. Viera \& bonnie jill Fergusson 2004) 
2. Operan dari rekan, Latihan ini mengharuskan anda untuk mengoper bola yang tepat mengarah pada anda. Ini merupakan latihan yang baik untuk melatih konsistensi ketepatan operan anda sejak awal. Disini anda di hruskan untuk mengoper bola kearah yang berjarak sama secara terus menerus. Cobalah juga untuk menjaga konsistensi ketinggian operan bola anda. Cara latihannya adalah mintalah seorang rekan untuk mengumpan bola pada anda, gunakan lengan depan anda, oper bola kembali kepada rekan anda. Rekan anda harus dapat menangkap bola tanpa melangkahkan kaki lebih dari satu langkah kearah manapun. Tujuan kesuksesan 20 kali operan lengan/passing bawah yang baik dari 25 kali usaha. Pemeriksaan kesuksesan; (a) bergerak kearah bola, persiapkan posisi, arahkan bola dengan landasan

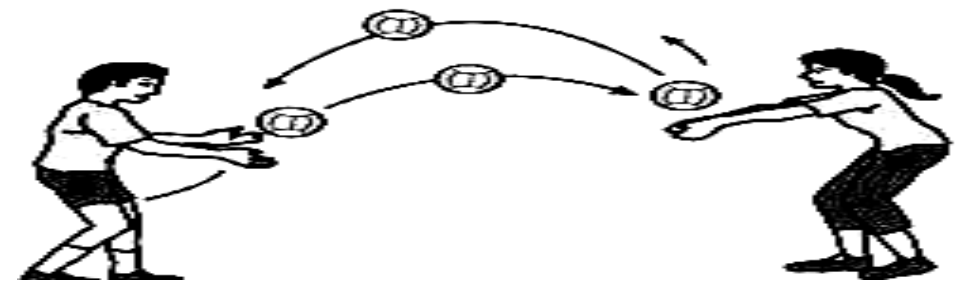

Gambar 2. Latihan Operan Dari Rekan

3. Melakukan passing bawah di area net dengan target melewati tinggi net, latihan ini melatih konsistensi penerimaan pukulan anda, melatih pergerakan kaki, juga membantu anda dalam mengawasi jatuhnya bola. Konsistensi dalam menjaga ketinggian bola sangat penting. Cara latihannya adalah lemparkan bola voli perlahan kearah anda dan gunakan operan lengan/passing bawah untuk menjaga bola tetap di udara. Pukul bola setinggi 8 sampai 10 kaki dengan menggunakan net sebagai acuan. Tetaplah berada dalam area seluas 10 kaki persegi. Tujuan kesuksesan 25 kali pukulan berturut dalam area seluas 10 kaki persegi. Pemeriksaan kesuksesan: (a) Menerima bola dengan rendah, (b) Julurkan kaki. (c) Kontrol bola.

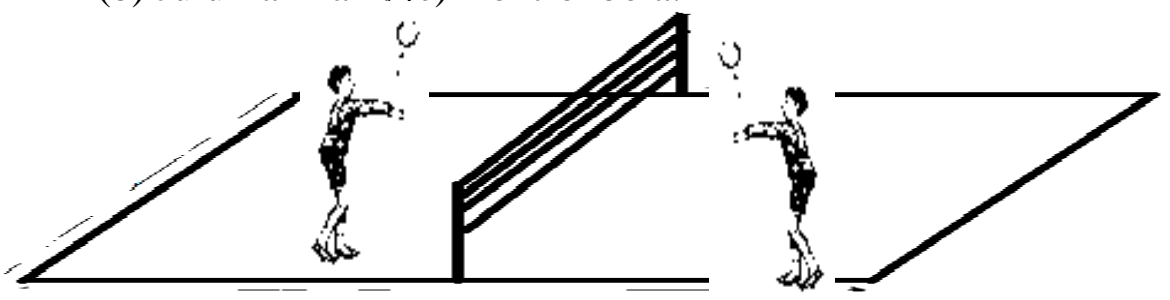

Gambar 3. Latihan Di Area Net

4. Mengoper Kearah Sasaran, dalam latihan ini pengumpan dapat mengatur tingkat kesulitan latihan. Pelempar dapat mmemulai dengan melemparkan bola kearah pemain, kemudian seiring dengan semkin mahirnya sipemain, tambahkan tantangan dengan mengarahkan umpan kekiri atau kekanan. Cara latihannya dengan 3 orang dalam 1 kelompok, 1 orang melemparkan bola melewati net kearah anda. 
Terima bola tersebut dan arahkan dengan menggunakan operan lengan depan/passing bawah kearah orang ketiga yang berada dimuka net. Sasaran menangkap bola tersebut untuk kemudian di kembalikan kepelempar. Tujuan kesuksesan 20 operan lengan depan yang akurat dari 25 kali usaha. Pemeriksaan kesuksesan; (a) Posisikan tubuh, (b) Landasan kearah sasaran, (c) Lengan sejajar dengan paha

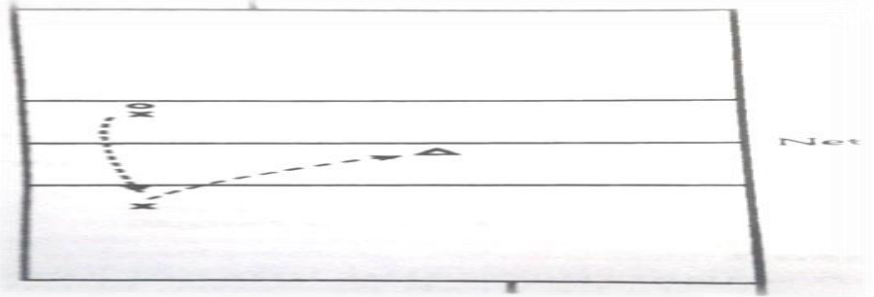

Gambar 4. Latihan Mengoper Kearah Sasaran, Barbara L. Viera \& Bonnie jill Fergusson (2004)

\section{Metode}

Penelitian ini menggunakan desain Penelitian Tindakan Kelas (PTK) yang melibatkan satu variabel bebas dan satu variabel terikat sebagai respon. Variabel bebas yaitu melalui Gaya Mengajar Latihan sedangkan variabel terikat adalah hasil belajar passing bawah permainan bola voli dengan rancangan pre-test dan post-test.

Sesuai dengan pendekatan penelitian ini, yaitu pendekatan kualitatif dengan jenis penelitian tindakan kelas maka peneliti ini dilakukan dalam dua siklus yang tiap siklusnya terdiri dari 4 tahapan sebagai berikut: 1) Perencanaan (planning), 2) Tindakan (acting), 3) Pengamatan (observing), 4) Refleksi (reflecting). Desain penelitian yang digunakan adalah:

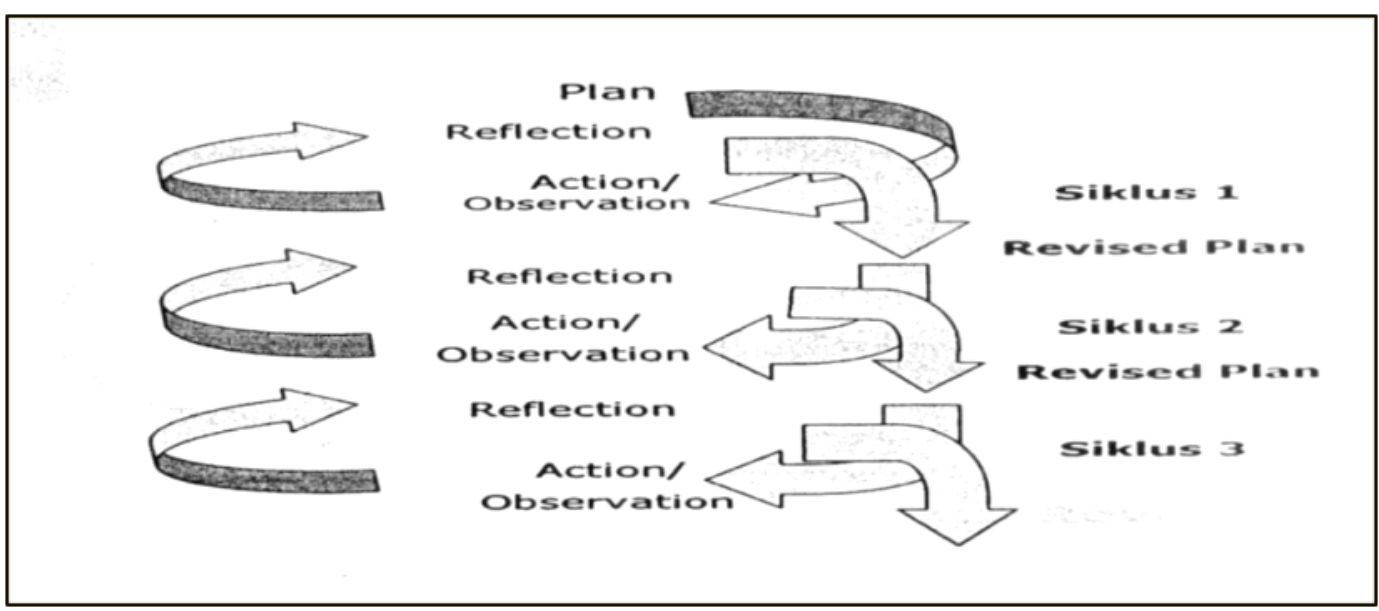

Gambar 5. Skema Siklus Dalam Penelitian Tindakan Kelas Arikunto (2015)

Analisa data yang dilakukan terdiri dari beberapa tahap diantaranya: (1) Reduksi Data, proses reduksi data dilakukan dengan cara menyeleksi, menyederhanakan dan mentransformasikan data yang telah disajikan dalam transkip catatan lapangan. Kegiatan reduksi data ini bertujuan untuk melihat kesalahan atau kekurangan siswa dalam pelaksanaan tes dan tindakan apa yang 
dilakukan untuk perbaikan kesalahan tersebut. (2) Paparan Data, dalam kegiatan ini yang diperoleh dari hasil belajar siswa dipaparkan dalam bentuk tabel dengan menggunakan rumus yang telah ditetapkan. Sesuai dengan buku Kriteria Ketuntasan Maksimal (KKM) mata pelajaran Pendidikan Jasmani Olahraga Kesehatan tingkat SMA Kurikulum KTSP, Depdiknas kurikulum KTSP (2007)

$$
\mathrm{KKM}=\frac{\text { Indikator } 1+\text { Indikator } 2+\text { Indikator } 3}{\text { Jumlah Deskriptor }(12)} \times 100 \%
$$

Jika indikator memiliki kriteria kompleksitas tinggi, daya dukung tinggi dan intake peserta didik sedang, maka nilai KKM nya adalah:

KKM = Kriteria Ketuntasan Minimal

Dengan Kriteria:

$0 \% \leq \mathrm{KKM}<74 \% \quad$ : Siswa belum tuntas dalam belajar

$75 \% \leq \mathrm{KKM} \leq 100 \%$ : Siswa telah tuntas dalam belajar

Dari uraian diatas dapat diketahui siswa yang belum tuntas dalam belajar dan siswa yang sudah tuntas dalam belajar secara individu. Selanjutnya dapat juga diketahui apakah ketuntasan belajar siswa secara klasikal dapat tercapai, dilihat dari persentase siswa yang sudah tuntas dalam belajar dapat dirumuskan sebagai beriku:

$$
\mathrm{PKK}=\frac{\text { banyak siswa yang memperoleh nilai } \geq 75 \%}{\text { banyak siswa keseluruhan }} \times 100 \%
$$

Keterangan: PKK (Persentase Ketuntasan Klasikal)

Berdasarkan kriteria ketuntasan belajar, jika dikelas tersebut telah terdapat minimal $85 \%$ siswa yang telah mencapai persentase penilaian atau nilai $\geq 75 \%$ maka ketuntasan secara keseluruhan terpenuhi.

\section{Pembahasan}

Penelitian ini dilaksanakan di SMA Swasta Darul Ilmi Murni Kabupaten Deli Serdang Tahun Ajaran 2017/2018. Penelitian dilaksanakan sesuai dengan jadwal pelajaran bola voli di kelas $\mathrm{X}$ yang menjadi subjek penelitian. Berikut ini adalah deskripsi data hasil penelitian yang di mulai dari data tes siklus I dan tes siklus II. Adapun deskripsi data penelitian yang diperoleh dapat dilihat pada tabel

\begin{tabular}{|c|c|c|c|c|}
\hline \multirow{2}{*}{ NO } & \multirow{2}{*}{ Perlakuan } & \multicolumn{3}{|c|}{ Aspek Yang Dinilai } \\
\hline & & Sikap Awal & Gerakan Pelaksanaan & Gerakan Lanjutan \\
\hline \multirow[t]{2}{*}{$\mathbf{1}$} & Post-test & Jumlah : 69 & Jumlah : 57 & Jumlah : 69 \\
\hline & Siklus I & NilaiRata-rata : 3,13 & Nilai Rata-rata : 2,59 & Nilai Rata-rata : 3,13 \\
\hline \multirow[t]{2}{*}{2} & Post-test & Jumlah : 76 & Jumlah : 60 & Jumlah : 75 \\
\hline & Siklus II & Nilai Rata-rata: 3.45 & Nilai Rata-rata : 2.72 & Nilai Rata-rata : 3.40 \\
\hline
\end{tabular}
dibawah ini:

Tabel 1. Deskripsi Hasil Belajar Passing Bawah Bola Voli Melalui Gaya Mengajar Latihan 
Berdasarkan tabel deskripsi hasil test passing bawah bola voli di atas dapat dilihat bahwa pada data post test siklus I dapat dilihat bahwa pada sikap awal/permulaan jumlahnya adalah 69 dengan nilai rata-rata 3,13, pada gerakan pelaksanaan jumlahnya adalah 57 dengan nilai rata-rata 2,59, kemudian gerakan lanjutan/akhir jumlahnya adalah 69 dengan nilai rata-rata 3,13. Selanjutnya pada post test siklus II dapat dilihat bahwa pada sikap awal/permulaan jumlahnya adalah 76 dengan nilai rata-rata 3.45, kemudian di gerakan pelaksanaan/perkenaan bola jumlahnya adalah 60 dengan nilai rata-rata 2.72, pada gerakan lanjutan/akhir jumlahnya adalah 75 dengan nilai rata-rata 3.40. Bisa kita lihat bahwa nilai ratarata di setiap indikator hasil passing bawah bola voli data siklus I dan siklus II terjadi peningkatan.

\section{Siklus I}

Pada siklus I terlihat bahwa kebanyakan siswa pada saat melakukan passing bawah bola voli siswa masih kurang seperti pada saat melakukan teknik dasar sikap awal banyak siswa pada kedua siku tidak lurus, saat melakukan gerakan pelaksanaan/perkenaan masih banyak siswa yang tidak merapatkan kedua siku sehingga ayunan tangan kearah bola tidak mengarah kelengan tangan, pada saat melakukan gerakan lanjutan/akhir siswa kurang mampu mengarahkan bola kesasaran, bola tidak di lambungkan dan kaki tidak melangkah kedepan untuk mengambil posisi siap kembali sesuai teknik dasar bola voli yang sudah diberikan.

Berdasarkan tes hasil belajar passing bawah bola voli siklus I dapat dilihat bahwa kemampuan siswa dalam melakukan teknik passing bawah bola voli lebih baik dari data awal sebelum siklus, walaupun perbaikannya belum seperti yang diharapkan. Dari 22 orang siswa terdapat 11 orang siswa (50\%) yang telah mencapai tingkat ketuntasan belajar. Sedangkan 11 orang siswa (50\%) belum mencapai ketuntasan belajar. Dengan nilai ketuntasan klasikal siswa (50\%) sehingga proses pembelajaran dilanjutkan kesiklus II.

Tabel 2. Deskripsi Hasil Belajar Siklus I Passing Bawah Bola Voli

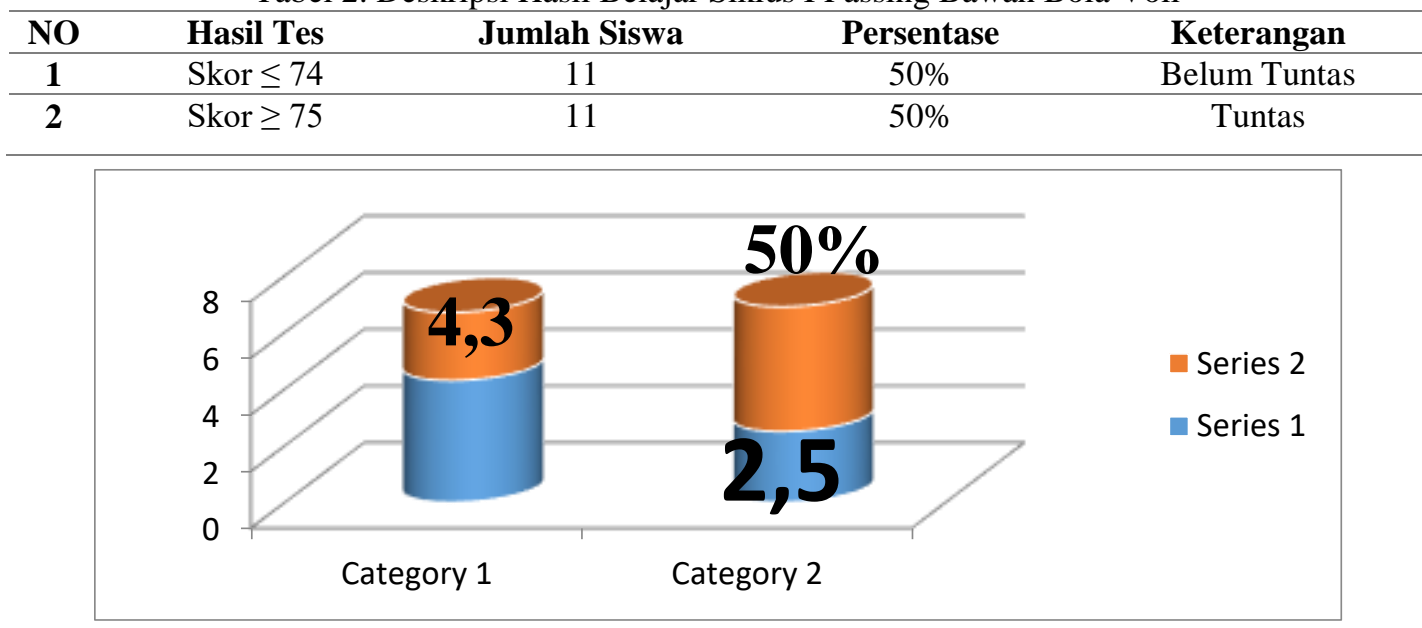

Gambar 6. Diagram Siswa Yang Tuntas Dan Belum Tuntas Pada Siklus I

PJKR_

http://jurnal.unimed.ac.id/2012/index.php/jpehr/index 


\section{Siklus II}

Berdasarkan tes hasil observasi dan hasil tes melalui fortofolio diperoleh data sebanyak 19 orang siswa telah mencapai tingkat ketuntasan belajar sedangkan 3 orang siswa belum mencapai tingkat ketuntasan belajar yang diharapkan. Nilai rata-rata siswa pada siklus II adalah 81,45 yang dapat dikatakan sudah memenuhi KKM yaitu 75 (tuntas). Tingkat ketuntasan belajar klasikal siswa sebesar $86,36 \%$ secara klasikal (85\%) sudah tuntas.

Tabel 3. Hasil Tes Siklus II Passing Bawah Bola Voli Melalui Gaya Mengajar Latihan

\begin{tabular}{ccccc}
\hline No & Hasil Tes & Jumlah Siswa & Persentase & Keterangan \\
\hline $\mathbf{1}$ & Skor $\leq 77$ & 3 & $13.63 \%$ & Belum Tuntas \\
\hline $\mathbf{2}$ & Skor $\geq 78$ & 19 & $86,36 \%$ & Tuntas \\
\hline
\end{tabular}

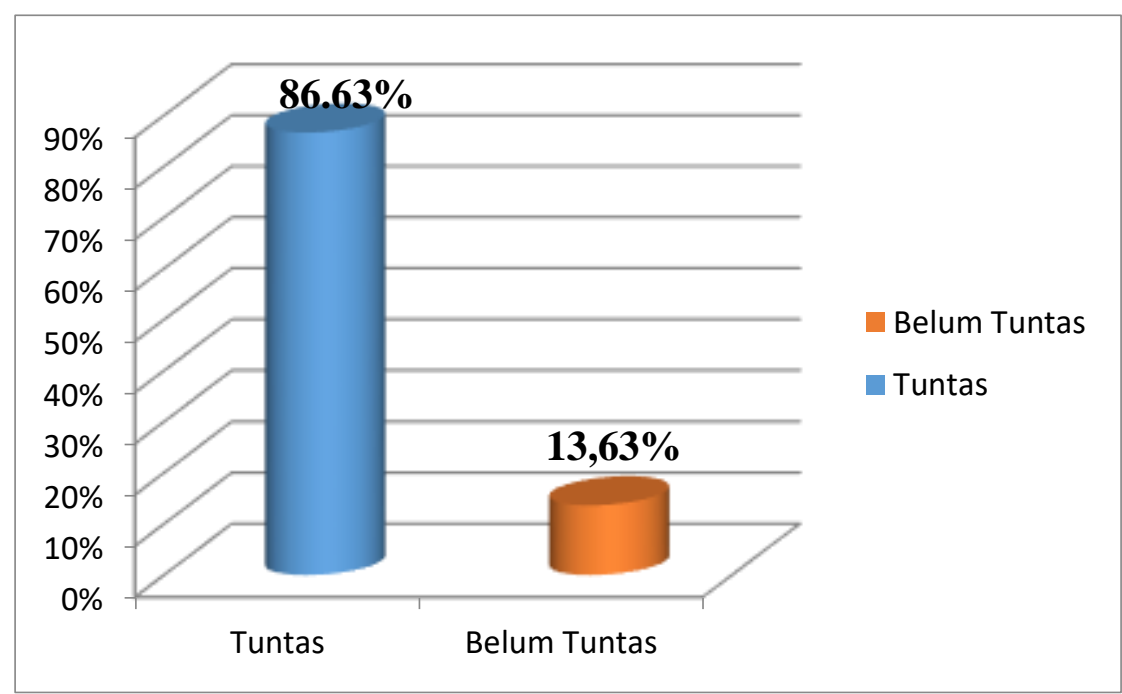

Gambar 7. Hasil Tes Siklus II Passing Bawah Bola Voli Melalui Gaya Mengajar Latihan

\section{Simpulan}

Berdasarkan hal itu maka dapat ditarik kesimpulan bahwa pembelajaran melalui gaya mengajar latihan dapat meningkatkan hasil belajar passing bawah bola voli pada siswa kelas X SMA Swasta Darul Ilmi Murni Kabupaten Deli Serdang Tahun Ajaran 2017/2018.

\section{Rujukan}

Abdullah, Arman dan Agus Manadji, 1994. UURI Tahun 1989, Dasar-Dasar Pendidikan Jasmani. Jakarta: Dirjen Pendidikan Tinggi

Bloom, 1956. Model Pembelajaran Inovatif. Yogyakarta: Gava media

Beutelstaahl, Dieter, 1978. Belajar Bermain Bola Volley. Bandung: Penerbit "Pionir Jaya"

Djamarah, 2006. Strategi Belajar Mengajar. Jakarta: Rineka Cipta

Durrwachter, Gerhard, 1984. Bola volley belajar dan berlatih sambil bermain. Jakarta: PT. Gramedia

PJKR_

http://jurnal.unimed.ac.id/2012/index.php/jpehr/index 
Roji, 1989. Pendidikan Jasmani. Jakarta: PT. Intan Pariwara

Husdarta dan Yudha, 2000. Belajar dan Pembelajaran, Jakarta: Dikjen Pendidikan Dasar dan Menengah

Lutan, Rusli, 2000. Strategi Belajar Mengajar Penjaskes. Jakarta: Departemen Pendidikan Nasional Dirjen Didasmen PPG-SLTP SETARA D-III

Muska Mosston, 1994. Teaching Physical Education. Ohio: Second Edition Charles E.Meil Publishing Co

Viera, Barbara L, 2004. Bola voli Tingkat Pemula. Jakarta: Penerbit Raja Grafindo Persada 